DOI https://doi.org/10.30525/978-9934-571-83-1-29

\title{
АПРОКСИМАЦІЯ ЗАКОНОДАВЧОГО РЕГУЛЮВАННЯ ЯКОСТІ ПОВЕРХНЕВИХ ВОД УКРАЇНИ ДО ПРАВА СС
}

\author{
Уберман В. І., Васьковець Л. А.
}

\section{ВСТУП}

Апроксимація водного законодавства України до екологічного права СС $\epsilon$ складовою частиною процесу наближення законодавства України загалом і екологічного законодавства зокрема до acquis communautaire. Наближення здійснюється за спеціальними програмами, що реалізуються органами державного управління, асоційованими 3 ними тематичними групами під проводом європейських консультантів та за проектами європейської (грантової) допомоги. Але при сучасній практичній реалізації розрізнених спроб точкової та фрагментарної апроксимації окремих правових інститутів виникають конфлікти (іноді принципові) з усталеною системою суспільних відносин та незмінених законодавчих норм, із вітчизняними науковими досягненнями та технічними принципами, iз практикою водоохоронної діяльності. У цій роботі досліджується один із центральних напрямів апроксимації, який стосується якості вод: складної та багатоаспектної проблеми наближення водного законодавства України до екологічного права СС.

Головними особливостями проблеми є:

- неможливість одночасної разової зміни законодавчих вимог до великого й багатозв'язного комплексу водних відносин, глибоко закорінених у механізм господарювання;

- необхідність уникнення перепон поточній водогосподарській діяльності під час економічної кризи та системної перебудови економіки України;

- недосконалість процедури сучасного українського законотворення.

Дослідження стану та можливостей адекватного відображення у Водному кодексі України (далі - ВКУ) та у низці підзаконних актів вимог європейського водного законодавства, викладених головним чином у Водній рамковій директиві (далі - ВРД) ${ }^{1}$, започатковано ще у 2003 р. Але тематика апроксимації вимог ВКУ до ВРД у частині якості вод не набула

\footnotetext{
${ }^{1}$ Водна рамкова директива СС 2000/60/ЕС. Основні терміни та їх визначення. EU Water Framework Directive 2000/60/EC. Definitions of Main Terms. Київ : 2006. 240 c. URL: https://www.twirpx.com/file/ 1527562/ (дата звернення 05.02.2019).
} 
належного відображення у сучасних дослідженнях через іï наукову новизну, нечіткий поділ та недотримання сфер водогосподарської й водоохоронної відповідальності між центральними органами державної влади. Представлені нижче результати досліджень грунтуються на матеріалах науково-дослідної роботи 2 .

Навіть побіжне порівняння ВКУ з ВРД дає змогу побачити принципові відмінності між цими актами. Створюється враження, що вони стосуються різних предметів. У ВКУ йдеться головним чином про водні об'єкти, систему водокористування, керівництво та організацію цієї діяльності, тоді як ВРД спрямована на забезпечення якості вод. Принципові відмінності виявляються вже на рівні базових юридичних визначень та понять. Така глибока розбіжність ускладнює, а у деяких аспектах й унеможливлює апроксимацію. Найбільш важливим і доступним напрямом зближення $\epsilon$ «екологізація» ВКУ, необхідність якої давно зазначалася ${ }^{3}$. Шлях екологізації вимагає чіткого розмежування водогосподарського та водоохоронного правових інститутів. Тому важливою невирішеною частиною загальної проблеми $\epsilon$ створення у водному законодавстві України еколого-правового інституту якості вод та ї̈ регулювання (ЕПІЯВР). Внаслідок перших спроб апроксимації (2016-2017рр.) текст ВКУ зазнав змін, тому далі використовуються позначення: ВКУ-15 - для тексту без змін, ВКУ-17 - для зміненого тексту.

Метою цієї роботи є оцінка стану ЕПІЯВР у водному законодавстві України, визначення та порівняння його головних особливостей 3 екологічним законодавством СС, від результатів якого залежать процес та кінцевий (водоохоронний) ефект апроксимації.

\section{1. Порівняння цілей, основних визначень ВКУ і ВРД, джерела вимог до якості вод в екологічному законодавстві ЄС}

Згадані у вступі принципові відмінності між ВКУ і ВРД добре видно $з$ порівняння галузевих цілей та обмежень цих актів. У преамбулі до ВРД зазначено таке:

- $\epsilon$ «потреба в законодавчому документі $Є С$ щодо екологічної якості» та «пропозиції щодо поліпшення екологічної якості поверхневих вод ЄС» (пар. 2);

\footnotetext{
${ }^{2}$ Розроблення наукового обгрунтування та пропозицій щодо критеріїв оцінки фізико-хімічного стану та стандартів якості поверхневих вод з метою наближення (апроксимації) водного законодавства України до права СС : звіт про НДР (остат.), Харків, УКРНДІЕП ; кер. В.І. Уберман; викон. В.С. Кресін [та ін.]. № ДР 0117U001484. Харків, 2017. 265 с.

${ }^{3}$ Гриценко А.В. Проект змін до Водного кодексу України / А.В. Гриценко, В.Р. Лозанський. Проблеми охорони навколишнього природного середовища та екологічної безпеки : збірник наук. пр. Харків : Факт, 2004. Вип. 26. С. 3-15.
} 
- «ця директива має на меті підтримати та покращити водне природне середовище в СС. Цей намір переважно стосується якості вод, що розглядаються. Регулювання кількості води є додатковим елементом у забезпеченні ії доброї якості» (пар. 19);

- «слід встановити загальні показники стану води щодо ії якості й там, де це потрібно для охорони довкілля, іiі кількості» (пар. 25).

На відміну від ВРД, у ст. 2 ВКУ щодо мети регулювання правових відносин визначено: «<..> 3 метою забезпечення збереження, науково обгрунтованого, раціонального використання вод для потреб населення i галузей економіки».

Тому найпростішим логічно обгрунтованим та альтернативним «екологізації» ВКУ шляхом апроксимації та подолання зазначених принципових розбіжності могло би стати розроблення та прийняття спеціального Закону України «Про якість вод».

Нині є два українських переклади ВРД: зазначений вище та переклад ${ }^{4}$, жоден з яких не має належних ознак та вказівок щодо його офіційного статусу. Варто констатувати принципову різницю в юридичних визначеннях гідрологічних термінів у ВКУ та у ВРД, яка спричиняе їх відмінність у правовому регулюванні. За ст. 1 ВКУ, базовим $\epsilon$ термін «водний об'єкт». У ВРД для цього головного гідрологічного поняття використовується термін "body of surface water" або "surface water body". Цей термін зазвичай перекладається як «поверхневий водний об'єкт» або «водойма». У ст. 2(10) ВРД цей термін визначається як "a discrete and significant element of surface water", тобто «окрема та значуща складова частина поверхневої води». Натомість, у ВКУ-17 для нього використано некоректний переклад: «масив поверхневих вод - поверхневий водний об'єкт або його частина» (пропущено важливий прикметник!), в якому йдеться про будь-яку частину. Отже, «масив вод» $\epsilon$ просторово найменшою неподільною (за гідрологічним, господарським або екологічним значенням) частиною певного водного об'єкта. Тобто, за визначенням ВРД, є межа довільного подрібнення просторового розміру, тоді як у визначенні ВКУ-17 така межа відсутня. Виявлену принципову помилку можна виправити внесенням такої зміни: «Масив поверхневої води - водний об'єкт або його частина, встановлена у відповідності до процедури ідентифікації». Процедура ідентифікації або виокремлення (картування) передбачена у п. А(1) Додатку VII ВРД.

Другою важливою еколого-правовою категорією у ст. 1 ВКУ є «якість води - характеристика складу і властивостей води, яка визначає іiі

\footnotetext{
${ }^{4}$ Директива 2000/60/ЄС Європейського Парламенту та Ради від 23 жовтня 2000 року, яка встановлює рамки для дій Співтовариства у сфері водної політики. URL: https://zakon.rada.gov.ua/laws/show/994_962.
} 
придатність для конкретних цілей використання». Така вторинна характеристика стосується цінності води для певного водокористувача, тобто іiі економічного значення. У ВРД юридичне поняття якості води відсутнє, а використовуються первинні характеристики: екологічний стан та хімічний стан (застосовано термін «status»). Ще одне суперечливе визначення стосується «забруднення вод», яке за ст. 1 ВКУ формулюється як «надходження до водних об'єктів забруднюючих речовин», а «забруднююча речовина - речовина, яка привноситься у водний об'єкт внаслідок господарської діяльності людини». У ст. 2(33) ВРД використано змістовно інші визначення: ““Забруднення” означає пряме чи непряме введення, в результаті діяльності людини, речовин чи тепла у повітря, воду чи землю, які можуть бути небезпечними для здоров'я людей або для якості водних екосистем, або наземних екосистем, що безпосередньо залежать від водних екосистем, яке призводить до пошкодження матеріальної власності або до припинення чи погіршення функціонування комунальних служб або інших законних користувачів довкілля», а «“Забруднювач” означає будь-яку речовину, яка може викликати забруднення, зокрема, речовини, перелічені у Додатку VIII». Принципова різниця полягає у слові «привноситься» (у ВКУ) та у можливості небезпечності (у ВРД). Перше за мовним тлумаченням означає «вносити в що-небудь щось додаткове або стороннє». А виявлення можливої небезпечності вимагає конкретизації умов та обставин події, визначення відповідних критеріїв. Отже, за ВКУ, забруднення вод з урахуванням якісних або кількісних ознак вмісту речовин характеризується появою у воді речовин, яких там не було до події забруднення, та/або збільшенням вмісту деяких речовин після такої події. Практика судових розглядів, в яких автори брали участь як експерти, свідчить, що така ознака $є$ цілком прийнятною та вирішальною для правозастосовної діяльності. Крім того, як зазначалося вище, якість вод у ВРД визнається або самостійною ијіллю, або головним інструментом досягнення екологічної якості, тоді як у ВКУ - лише обмеженням для використання води.

Варто зазначити відмінність ще одного базового визначення у ст. 2 ВРД: «"Екологічний стан” $є$ виразом якості структури і функціонування водних екосистем, пов'язаних із поверхневими водами, класифікованими згідно 3 Додатком V», від визначення у ст. 1 ВКУ: «екологічний стан масиву поверхневих вод - інтегрований показник якості масиву поверхневих вод, що визначається за біологічними, гідроморфологічними, хімічними та фізико-хімічними показниками». За умови розуміння прикметника «інтегрований» у сенсі «комплексний», друге визначення, крім його 
об'єктної помилковості, $є$ значно ширшим за обсягом врахованої інформації і більш жорстким за виразом якості.

Можна констатувати, що початковий етап апроксимації до вимог ВРД характеризується термінологічними помилками, непорозуміннями та невідповідностями. 335 юридичних термінів, які утворюють у ВРД понятійну базу щодо якості вод, лише 4 терміни нині присутні у ВКУ, але й вони змістовно відрізняються від визначень ВРД.

Центральне ядро європейського ЕПІЯВР утворюється ВРД, яка належить до сектору водного законодавства СС. Аналітичний розгляд екологічного законодавства СС свідчить про наявність комплексного зв'язку ВРД з іншими загальноекологічними, дочірніми, пов'язаними та суміжними законодавчими актами СС. Такий зв'язок широко охоплює складники природоохоронного законодавства СС i створює багато складних проблем під час спроб дотримання вимог ВРД. До головних (iз позицій якості вод та іiі регулювання) належать, включаючи ВРД, 9 законодавчих джерел і довідкових матеріалів, структура зв'язків між якими наведена на рисунку 1, а саме: Directive 2008/1/EC concerning integrated pollution prevention and control (IPPCD); Directive 2010/75/EU on industrial emissions (integrated pollution prevention and control) (IED); Directive 2008/105/EC on environmental quality standards in the field of water policy (EQSD); Directive 2013/39/EU as regards priority substances in the field of water policy; Directive 2006/11/EC on pollution caused by certain dangerous substances discharged into the aquatic environment of the Community (DSD); Regulation (EC) No 166/2006 concerning the establishment of a European Pollutant Release and Transfer Register (PRTR); Regulation (EC) No 1907/2006 concerning the Registration, Evaluation, Authorization and Restriction of Chemicals (REACH); Довідкові документи для IPPCD та IED щодо найкращих доступних технологій (ВАТ або НДТ)).

Зазначеними джерелами (регламентами, директивами та довідниками) створюється основа ЕПІЯВР СС. Найважливішими варто вважати зв'язки ВРД із директивами IPPCD, IED, EQS, DSD. Всередині секторального водного законодавства та у предметно пов'язаних із ним актах до зазначеного інституту належать, щонайменше, три сукупності джерел права, якими регламентуються якість вод для різних видів її використання, скиди (емісії) забруднюючих речовин (ЗР), методи вимірювання та відбирання проб води.

3 точки зору апроксимації така складна структура джерельної бази, кожен акт якої містить значну кількість норм щодо якості води та іiі регулювання, вимагає адекватного відображення у водному законодавстві України. Вочевидь, ані ВКУ-15, ані ВКУ-17 та пов'язані з ними підзаконні 
акти не відповідають таким вимогам. Через викладене здійснення наближення вимагатиме багато часу та зусиль у законо- та нормотворчій діяльності.

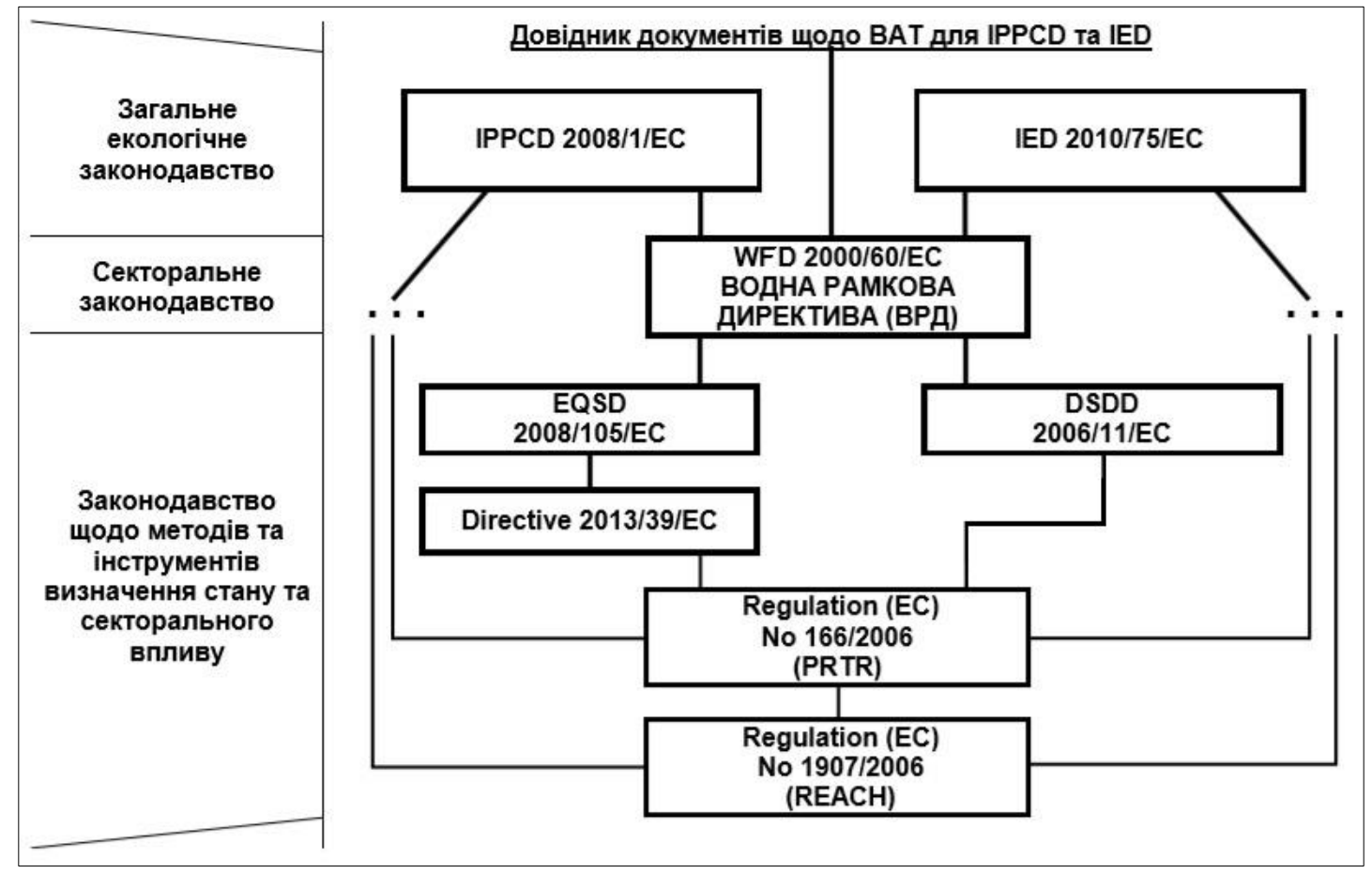

\section{Рис. 1. Загальна структура джерел ЕПІЯВР СС (пояснення у тексті)}

Аналітичне порівняння ВКУ з ВРД виявило принципові відмінності цих актів. Найбільша за обсягом та значенням невідповідність стосується ЕПІЯВР. Зазначений інститут в явному та акцентованому вигляді практично відсутній в українському водному законодавстві.

\section{2. Еколого-правовий інститут якості вод та її регулювання}

в законодавстві України, тенденції наближення до acquis

Для країн - не членів ЄС зі Східної Свропи, Кавказу та Центральної Азії (СЄКЦА) європейськими експертами пропонуються значно «пом'якшені» критерії визначення якості поверхневих вод (порівняно 3 використовуваними в колишньому СРСР нормативами гранично допустимих концентрацій (ГДК) забруднюючих речовин (ЗР)). Такий підхід грунтується на визнанні принцииоової відмінності між иіілями якості води та стандартами (як регулюючими нормативами для оцінки та класифікації стану вод). Експерти вважають, що у СЄКЦА зазначені поняття змістовно ототожнюються, тоді як в СС вони мають істотно різне 
розуміння. Використання європейського підходу вимагає кардинальної зміни української парадигми водоохоронної політики.

Україна має розвинене національне законодавство стосовно вимог до якості поверхневих вод для основних видів ії використання. Крім двох базових законодавчих актів (Закон України «Про охорону навколишнього природного середовища» та ВКУ) до суміжних галузевих актів належать 8 законів України. Конкретні вимоги до якості поверхневих вод для задоволення потреб при різних видах водокористування встановлено в 11 державних та галузевих нормативних і нормативно-технічних документах. Найбільш повним джерелом об'єктивної науково обгрунтованої нормативної інформації є державний нормативно-правовий документ щодо гігієнічних вимог до поверхневих вод СанПиН № 4630-88. За цим документом протягом багатьох років здійснювався визначальний вплив на:

- якість поверхневих вод та стримування iї погіршення;

- водокористування у частині скидання ЗР у поверхневі водні об'єкти зі зворотними водами;

- державний контроль водокористування;

- екологічне оподаткування скидання ЗР безпосередньо у водні об'єкти;

- економічні санкції за перевищення дозволених показників скидання.

Нині це джерело визнано таким, що не застосовується на території України 31 січня 2017 р. Відсутність власного українського нормативноправового документа аналогічного призначення створює критеріальний вакуум щодо визначення, оцінювання та регулювання якості вод. Причини цього викладено у роботі ${ }^{5}$. Другим за соціальним значенням (але першим за екологічним змістом) джерелом критеріальних вимог до оцінки фізикохімічного стану поверхневих вод України $є$ рибогосподарські ГДК, що містяться у документах колишнього СРСР. Ця низка нормативів за понад 25 років існування зазнала в Україні лише незначних змін непринципового характеру. Найважливіші завдання щодо якості поверхневих вод та впливу на неї і відповідальність за результати покладено на Мінприроди України. У сферу діяльності Держводагентства України як водогосподарського органу входить обмежений обсяг функцій у зазначеному напрямі. Насправді ж цей орган, впроваджуючи інтегровані підходи в управлінні водними ресурсами за басейновим принципом, перебрав на себе деякі завдання стосовно ЕПІЯВР. Більшість запропонованих ним змін стосувалася додавання нових та коригування наявних юридичних визначень у ст. 1 ВКУ, яка нині містить 74 визначення (при 112 статтях у

\footnotetext{
${ }^{5}$ Уберман В.И., Васьковец Л.А. Аппроксимация водного законодательства Украины к праву ЕС и экологическая безопасность водопользования. Актуальні питання громадського здоров'я та екологічної безпеки Украӥни : збірник тез допов. наук.-практ. конф. (чотирнадцяті марзеєвські чит.). Вип. 18, 11-12 жовтня 2018 р. / оргкомітет А.М. Сердюк (гол.) [та ін.]. Київ : «Рекл. агент. TR Studio», 2018. С. 65-67.
} 
ВКУ), що порівняно з 41 визначенням у ст. 2 ВРД виглядає надмірним. Така неспівмірність $є$ одним 3 аргументів на користь створення спеціального Закону України «Про якість вод».

Зміни у ст.ст. $21^{1}$, 35-38 ВКУ безпосередньо торкнулися ЕПІЯВР. На шляху адаптації ВКУ до ВРД звертає на себе увагу відсутність в українському акті центральних визначень ВРД щодо якості вод та іiі регулювання: «небезпечні речовини», «пріоритетні речовини», «екологічний стандарт якості» (ЕСЯ), «комбінований підхід» та «водні послуги». 3 них ключовим для ЕПІЯВР є ЕСЯ. Для цього терміна у ст. 37 ВКУ введено формальний відповідник «екологічний норматив якості води масивів поверхневих <..> вод» (ЕНЯ). Такий ЕНЯ треба розуміти як єдиний фіксований спосіб перетворення конщентрацій ЗР та показників якості води у характеристику якості. Вирішення головного питання щодо визначення та конкретизації цього способу покладено на Мінприроди України. Отже, ЕНЯ варто розглядати як алгоритмізоване логікоматематичне однозначне перетворення множини ЗР та показників якості води на градуальне або категорійне значення якості. Але порівняння 3 визначенням у ст. 2(35) ВРД свідчить про суттєві відмінності понять: за ВРД ЕСЯ - «це концентрація окремої речовини-забрудника або групи речовин у воді, осаді або біоті, яку не можна перевищувати, щоб захистити здоров'я людини та довкілля», тобто ЕСЯ утворюють певну множину, що відповідає ЗР або їх групам. Треба зазначити, що у другому зі згаданих перекладів ВРД екологічних стандартів взагалі немає, натомість використано термін «стандарт якості довкілля». ЕСЯ визначається (скалярно) для окремої ЗР або групи речовин у воді, осадах чи біоті (для скалярного аргументу), у кожній точиі масиву вод, тоді як ЕНЯ визначається для цілого масиву вод за множиною ЗР та показників якості лише води (тобто ЕНЯ $\epsilon$ комплексним показником). ЕСЯ використовуються, зокрема, з метою «регулювання забруднення у його джерелі» (за пар. 40 Преамбули ВРД), тоді як ЕНЯ має двохцільове призначення: для «оцінки екологічного та хімічного станів масиву поверхневих вод <..> та визначення комплексу водоохоронних заходів» (ст. 37 та ст. $21^{1}$ ВКУ), тобто $i$ з метою оцінки, $i$ з метою регулювання. Отже, ЕСЯ та ЕНЯ не збігаються ані за призначенням, ані за формою та способом виразу.

Однією з головних відмінностей ВКУ від ВРД також є визначення цілей регулювання скидання ЗР: у ВРД йдеться про ЕСЯ, а у ВКУ - про ЕНЯ. Таким чином, стосовно перших кроків наближення ВКУ до ВРД варто констатувати наявність істотних розбіжностей в ЕПІЯВР.

Головним напрямом діяльності 3 поліпшення якості поверхневих вод вважається регулювання скидання ЗР із точкових джерел. Найбільш 
розвиненою гілкою українського ЕПІЯВР у зазначеному напрямі $\epsilon$ нормативне регулювання надходження ЗР у водні об'єкти внаслідок водокористування (зі зворотною водою). Тому важливою складовою частиною ЕПІЯВР $є$ підінститут нормативного регулювання надходження ЗР (ПНРНЗР) у водні об'єкти внаслідок водокористування. Саме на таке регулювання було спрямовано 5 головних підзаконних нормативно-правових актів у галузі охорони вод, розроблених у 19962002 pp. Деякі 3 них мають сучасні версії, орієнтовані на ВКУ-17. Найважливішими для регулювання є Порядок та Перелік ${ }^{6}$ i Правила ${ }^{7}$. Варто зазначити, що у 2017 р. зміст двох перших джерел було істотно змінено.

Перший крок щодо наближення ЕПІЯВР полягав у розробленні Держводагентством українського переліку ЗР для визначення хімічного стану масивів поверхневих вод та екологічного потенціалу штучного або істотно зміненого масиву поверхневих вод. Принциповим недоліком цього документа є повна відсутність категоризації $3 P$ за їх походженням, властивостями та небезпекою для довкілля. Зокрема, відсутня збиральна назва (або групова екологічна ознака) для ЗР, тоді як у ВРД та в інших законодавчих джерелах СС використовується назва "priority substances", тобто «пріоритетні речовини». Це саме ті речовини, на боротьбу із вмістом яких у воді спрямована ВРД. Відмова від зазначеної категоризації робить ЕПІЯВР безцільним. Крім того, у ВДР використовуються терміни "hazardous substances" (небезпечні речовини), "main pollutants" (головні забруднюючі речовини), "other substances" (інші речовини) та "pollutant" (речовина-забрудник). Така ієрархія ознак є екологічно та господарськи зумовленою. Відсутність у Переліку та у ВКУ категорійної ознаки ЗР викликає кілька важливих помилок, зокрема:

- викривлення характеру впливу речовин, які не пов'язуються із вказівками на їх пріоритетний характер, що не відповідає вимогам ст. 16(2) ВРД;

- створення вичерпного переліку речовин задля визначення хімічного стану масивів поверхневих вод та екологічного потенціалу штучного або істотно зміненого масиву поверхневих вод, що не відповідає визначенню "specific pollutants" («специфічних речовин-забрудників») у Додатку V до ВРД та призводить до ігнорування "indicative list of the main pollutants"

\footnotetext{
${ }^{6}$ Правила охорони поверхневих вод від забруднення зворотними водами» (затв. постановою Кабінету Міністрів України від 25 березня 1999 р. № 465). URL: http://zakon0.rada.gov.ua/laws/show/465-99-П .

${ }^{7}$ Про затвердження Порядку розроблення нормативів гранично допустимого скидання забруднюючих речовин у водні об'єкти та перелік забруднюючих речовин, скидання яких у водні об'єкти нормується (затв. постановою Кабінету Міністрів України від 11 вересня 1996 р. № 1100 (із змінами)). URL: https://zakon.rada.gov.ua/go/1100-96-п.
} 
(«індикативного переліку основних речовин-забрудників») із Додатку VIII до ВРД.

У ВРД серед пріоритетних $\epsilon$ «пріоритетні небезпечні речовини». Речовинний склад українського переліку повністю скопійовано з Додатку $\mathrm{X}$ ВРД (за його сучасним станом). Це формально відповідає вимогам до держав-членів $€ С$, але не відповідає факту відсутності в України членства в $\mathrm{CC}$, сучасним особливостям, перехідному характеру української економіки та охорони вод, ії відмінності від європейської і неадекватності сучасного переліку європейських пріоритетних ЗР українському реаліям. Деякі питання щодо відповідності Порядку та Переліку водному законодавству України розглянуто у статті В.I. Убермана ${ }^{8}$. Подальші кроки української апроксимації стосувалися проектів змін, які готувалися у 2017-2018 pр. Аналіз ефекту таких змін стане можливим лише з часом.

\section{3. Український еколого-правовий підінститут нормативного регулювання надходження забруднюючих речовин у водні об'єкти внаслідок водокористування, його відповідність acquis}

Головним джерелом норм ПНРНЗР є Правила. Цей документ у частині якості вод та іiі регулювання грунтується на принципах, найважливіші 3 яких мають сумнівну або помилкову відповідність законодавчим актам вищого рівня та є хибними з інженерно-екологічної точки зору. Зокрема, у п. 6 Правил використовується законодавчо та нормативно невизначене поняття: «ступінь забрудненості водного об'єкта», яке ототожнюється (за п. 2 Правил) 3 «категорією якості води». Також у п. 7 Правил визначено принцип нормування якості води водного об'єкта, за яким ігнорується головна законодавча вимога поетапного досягнення ЕНЯ (ст. 38 ВКУ), до речі, останній термін відсутній у визначенні термінів у п. 2 Правил. Вочевидь, цей принцип не відповідає ВРД. Правила (у п. 8) фактично визнають існування зон змішування (33) зворотної та природної води (тобто ділянок, де можуть порушуватися нормативні вимоги до якості вод) обмеженого розміру, вимагають виділення зон особливого режиму якості. Але якщо у ВКУ не передбачено наявності 33 (або осередків забруднення), то у водному секторальному законодавстві $€$ С існування та властивості 33 узаконено ст. 4 директиви EQS. Найбільшим недоліком зазначеного принципу є першочергове спрямування водоохоронної діяльності не на боротьбу із забрудненням в його джерелі, а на господарське використання асимілюючої спроможності самого водного об 'єкта. Стосовно очищення зворотної води Правила (п. 16) не враховують реальні властивості систем

\footnotetext{
${ }^{8}$ Уберман В.И. Целевые и эколого-химические требования к разработкам нормативов сбросов загрязняющих веществ. Екологічна безпека: проблеми і иляхи вирішення : збірник наук. стат. XIII міжнар. наук.-практ. конф., м. Харків, 11-15 вер. 2017. УКРНДІЕП, Харків : Райдер, 2017. С. 384-390.
} 
водовідведення, особливості їх проектування та використання, а саме: ігнорують нерегульованість (або обмежену регульованість) очисних споруд наявних водокористувачів. Більшість таких споруд збудована за застарілими проектами, багато років експлуатувалася 3 фіксованими та 3 погіршеними проти проектних характеристиками. Ефективне використання зазначеної норми вимагає перевірки властивості регульованості конкретних очисних споруд і змоги забезпечення ними потрібного ступеня регулювання у певний строк 3 прийнятними для водокористувача економічними показниками.

Стосовно нормативного регулювання скидання ЗР Правила (п. 18) викривляють цільові вимоги ст. 38 ВКУ і незаконно їх змінюють. В умовах фактичної відсутності ЕНЯ води, передбаченого ст. 38 ВКУ, можна стверджувати, що усі нормативи гранично допустимих скидів (ГДС) речовин, що встановлювалися водокористувачам із середини 1995 р., мають сумнівну законність визначення. Крім того, використання принципу «емісія - іммісія», тобто ГДК $\rightarrow$ ГДС для усіх скидів, не відповідає концепції ЕСЯ та комбінованому підходу до регулювання скидання, визначеному у ст. 10 ВРД.

У Правилах (п. 19) для трьох головних показників складу стічних вод широкої і важливої категорії водокористувачів передбачено фіксацію («заморожування») застарілих (50-річної давнини), але й донині чинних технологій очищення. Крім того, використано поняття «нормативів гранично допустимого вмісту», яке у ВКУ не встановлено. Щодо скидання такими водокористувачами інших ЗР, то законодавчий припис ст. 38 ВКУ також порушується: цільовою вимогою для нормування $\epsilon$ «за умови, що досягнута категорія якості води при цьому не погіршиться». Отже, у цих випадках про досягнення ЕНЯ навіть не йдеться. Насправді Правила $\epsilon$ рудиментом соціалістичної охорони вод. За принципами кодифікації законодавчих актів вимоги Правил мали би включатися у ВКУ як складники ЕПІЯВР, але при цьому самі Правила як окремий акт стають непотрібними.

Значний, а іноді й визначальний, незаконний і недопустимий вплив на засоби та інструменти регулювання якості вод чиниться з боку суто нормативно-методичного документа «Інструкція про порядок розробки та затвердження гранично допустимих скидів (ГДС) речовин у водні об'єкти iз зворотними водами (затв. наказом Мінприроди України від 15.12.1994 р. № 116, зареєстр. в Мін’юсті України 22 грудня 1994 р. за № 313/523)» (Інструкція). У цьому джерелі невідповідності вимогам ВКУ починаються 3 базових визначень. Найбільш принциповим недоліком варто визнати вимогу «урахування оптимального розподілу асимілюючої спроможності», яка реалізується через хибний для умов ринкової економіки «басейновий 
розрахунок» ГДС. Крім того, що господарське використання властивостей водного об'єкта не відповідає законодавству ЄС, такий вид розрахунків ГДС є особливо шкідливим для сучасної моделі економічного устрою України, для здійснення конкурентного господарювання та для екологоекономічної діяльності. «Басейновий розрахунок ГДС» консервує у сфері водокористування принцип колишньої соціалістичної економіки: централізоване командно-адміністративне господарювання. При використанні такого розрахунку здійснюється підміна понять та їх перекручування: прикметник «басейновий» розуміється не в сенсі «басейнового принципу управління», як у сучасному визначенні ст. 1 ВКУ-17, а неправомірно переноситься на особливості визначення нормативів скидів ЗР. У п. 2.14 Інструкції зазначається цільове спрямування басейнового принципу розрахунку, який «забезпечує мінімізаиію сумарних витрат на досягнення ГДС» [виділено авторами]. Отже, так званий «басейновий розрахунок ГДС» спрямовано на реалізацію одного з головних механізмів соціалістичної економіки, за яким витрати на охорону довкілля централізовано розподілялися державою, яка фінансувала відповідні водоохоронні заходи. Такий еколого-економічний підхід (і відповідний розрахунок) є неприпустимим у сучасних умовах: він робить економічну діяльність водокористувачів залежною один від одного, порушує вимоги до економічної конкуренції і не може бути інформаційно забезпеченим вихідними даними для розрахунків. Правовою підставою індивідуального (окремого для кожного водокористувача) розрахунку ГДС $\epsilon$ юридичне визначення цього нормативу у ст. 1 ВКУ, що змінило застаріле визначення ГДС із нормативно-технічного документа колишнього СРСР: ГОСТ 17.1.1.01-77, на якому до цього часу грунтується Інструкція.

Коротке порівняння систем нормативного регулювання якості поверхневих вод в Україні та ЄС наведено у табл. 1. У цій таблиці варто звернути увагу на невідповідність вимог Правил вищому акту українського водного законодавства, а також на більшу «гнучкість» європейських нормативів стосовно речовин, які не належать до пріоритетних та/або небезпечних.

За вимогою п. 13 Порядку, методичне забезпечення розроблення нормативів ГДС забруднюючих речовин встановлюється Мінприроди. Таке забезпечення $\epsilon$ складним науково ємним документальним, комп'ютерно-програмним та інформаційним комплексом, який, своєю чергою, має розроблятися профільними науковими установами за спеціальними технічними вимогами, що визначаються у тендерній документації на закупівлю такого забезпечення. Враховуючи складний зв'язок українського ПНРНЗР 3 екологічним законодавством $\mathrm{CC}$ та неможливість одночасної апроксимації до джерел права, зазначених у табл. 
1, згадане методичне забезпечення (МЗ) має розроблятися поетапно відповідно до кожного етапу апроксимації. Варто зазначити, що до складу М3 входить Інструкція 3 розроблення нормативів ГДС та програмний продукт, який забезпечує виконання математичного моделювання, необхідних розрахунків та підтримання інформаційних баз даних. Нині можна визначити чотири таких основних етапи, наведених у табл. 2. Нульовий етап передбачає виправлення у чинній Інструкції більшості невідповідностей українському водному законодавству за станом на 2015 р. Перший етап спрямовано на реалізацію вимог українського водного законодавства (за станом на 2017 р.) та часткову реалізацією М3 відповідних норм Директиви 2008/105/ЄС. Повна реалізація здійснюється на другому етапі. Третій та четвертий етапи полягають у забезпеченні дотримання головних вимог Директиви 2008/1/СС та Директиви 2010/75/EC.

Таблиця 1

Порівняльна структура нормативного регулювання якості поверхневих вод за водним законодавством України та СС

\begin{tabular}{|c|c|c|c|c|}
\hline $\begin{array}{c}\text { Джерела } \\
\text { права }\end{array}$ & $\begin{array}{c}\text { Джерела } \\
\text { емісій (скидів) } \\
\text { 3Р: } \\
\text { норматив }\end{array}$ & $\begin{array}{c}\text { Зона, } \\
\text { прилегла до } \\
\text { джерела } \\
\text { емісій: } \\
\text { довжина, } \\
\text { норматив }\end{array}$ & $\begin{array}{c}\text { Ділянка } \\
\text { водного } \\
\text { об'скта: } \\
\text { норматив }\end{array}$ & $\begin{array}{c}\text { Норматив для } \\
\text { зони: } \\
\text { водокористування } \\
\text { /захисної / } \\
\text { охоронної }\end{array}$ \\
\hline ВКУ & ГДС & 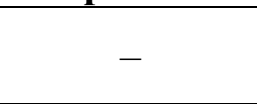 & $\begin{array}{l}\text { ЕНЯВ: } \\
\text { КЯВ } / n\end{array}$ & ГДК \\
\hline Правила & ГДС & $\leq 500$ м; ГДК & $\mathrm{K} Я \mathrm{~B} / n$ & ГДК \\
\hline $\begin{array}{c}-\ll-\text { для } \\
\text { КСБО }\end{array}$ & ГДВ Ксьо; ГДС & 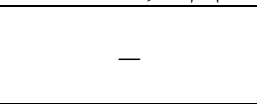 & КЯВ & - \\
\hline ВРД & НДТ; ГВЕ & - & ЕСЯ & КЯ \\
\hline $\begin{array}{c}\text { EQSD } \\
\text { (екологічні } \\
\text { стандарти } \\
\text { якості води) }\end{array}$ & - & $\leq 33$; ЕСЯ & ЕСЯ & - \\
\hline $\begin{array}{c}\text { DSDD (щодо } \\
\text { небезпечних } \\
\text { речовин) }\end{array}$ & $\begin{array}{c}\text { Стандарти } \\
\text { (нормативи) } \\
\text { емісії: ГК; ГС }\end{array}$ & $\leq 33$ & - & - \\
\hline
\end{tabular}

Абревіатури: ГДВксбо - гранично допустимий вміст окремих ЗР для комунальних споруд біологічного очищення; НДТ - найкращза доступна технологія; ГВЕ - гранична величина емісії; 33 - зона змімування; ГК - граничні концентрації; ГС - граничні скиди; КЯВ - категорія якості води, $n$ - номер етапу досягнення; ГДК - гранично допустима концентрація ЗР (для господарсько-побутового або рибогосподарського) водокористування; КЯ - критерій якості води в контрольному створі; інші абревіатури визначено у тексті. 


\section{Таблиця 2}

Етапи створення методичного забезпечення розроблення нормативів гранично допустимого скидання забруднюючих речовин при апроксимації до законодавства СС

\begin{tabular}{|c|c|c|}
\hline Етап & $\begin{array}{c}\text { Вимоги українського } \\
\text { законодавства }\end{array}$ & $\begin{array}{c}\text { Вимоги свропейського } \\
\text { законодавства }\end{array}$ \\
\hline 0 & Інструкція 1994- ВКУ-2015 & - \\
\hline 1 & Інструкція 1994- ВКУ-2017 & ВРД (частково) + EQSD (частково) \\
\hline 2 & - & ВРД (частково) + EQSD (повністю) \\
\hline 3 & - & BPД + EQSD + DSDD \\
\hline 4 & - & ВРД + EQSD + DSDD +IPPCD + IED \\
\hline
\end{tabular}

3 метою узгодження українського ПНРНЗР 3 екологічним законодавством СС пропонуються такі заходи:

1) включити у ВКУ поняття:

- стандартів екологічної та хімічної якості (EQS та CQS відповідно);

- встановлюваної зони змішування (MZ);

- найкращої доступної технології (ВАТ);

2) прийняти підзаконні акти та розробити інструктивно-методичне забезпечення щодо:

- практичного визначення, встановлення та контролю EQS та CQS;

- визначення характеристик MZ та контролю за ними;

- запровадження, підтримання та розвитку системи інформаційного забезпечення щодо ВАТ, включаючи державний реєстр ВАТ у галузі очищення стічних вод;

3) встановити у повному обсязі списковий механізм (за ВРД) регламентації речовинного складу води, який $\epsilon$ важливим базовим принципом оцінки та регулювання якості вод;

4) розробити МЗ щодо узгодження чинної Інструкції 3 вимогами чинного водного законодавства України. Подальше існування цього документа у незмінному вигляді створює умови для виникнення перерв у спеціальному водокористуванні в частині водовідведення, скиданні ЗР до водних об'єктів та інших перешкод водогосподарській діяльності, а також для погіршення якості поверхневих вод. 


\section{ВИСНОВКИ}

Між ВРД та ВКУ $є$ принципові відмінності та протиріччя, які перешкоджають апроксимації останнього до екологічного законодавства ЄC. Усунення цих перешкод можливе шляхом «екологізації» ВКУ та створення чітко акцентованого повномірного ЕПІЯВР, що включає ПНРНЗР як інструмент впливу на антропогенне надходження ЗР. Юридичні визначення основних гідрологічних термінів та екологічних показників якості вод у ВКУ та ВРД істотно відрізняються і вимагають гармонізації. Складна структура джерельної бази екологічного права $Є С$ не має адекватного відображення у законодавстві України. Головні підзаконні акти українського водного законодавства та нормативно-методичні документи, за якими здійснюється практичне регулювання якості вод, $є$ вкрай застарілими і протягом багатьох років не відповідають вимогам ВКУ. Створення нових редакцій таких актів, повністю узгоджених із законодавчими актами, є нагальним завданням. За водним законодавством України та екологічним законодавством $€ C$ нормативне регулювання якості поверхневих вод у ставленні до широкого кола ЗР та до джерел їх надходження мають істотні розбіжності, які вимагають усунення шляхом розроблення відповідних підзаконних актів. До першочергових подальших робіт належать: уніфікований офіційний переклад ВРД, максимально наближений до української науково-технічної термінології; порівняльно-термінологічний аналіз фактичного стану водного законодавства ЄС та України, інституційне реформування останнього в напрямі створення структурно виділеного та системно організованого ЕПІЯВР, починаючи з принципів, базових понять та юридичних визначень. Запропоновано заходи з поетапного узгодження українського ПНРНЗР з екологічним законодавством СС. Точкова (або фрагментарна) апроксимація, яка здійснювалася у 2016-2017 pp., в частині якості вод суперечить усталеній системі суспільних відносин, вітчизняним науковим досягненням та екологічним принципам, інженерній практиці і не може оцінюватися як вдала.

\section{АНОТАЦІЯ}

Розглядаються еколого-правові проблеми, що виникають у процесі апроксимації водного законодавства України до екологічного законодавства ЄС. Досліджується інститут якості вод та іiі регулювання, а також підінститут нормативного регулювання антропогенного надходження забруднюючих речовин у водні об'єкти. Визначено структуру джерел правових норм у законодавствах $Є C$ та України. 
Виявлено принципові розбіжності у цільовій спрямованості головних законодавчих актів, відмінності юридичних визначень основних термінів та підходів до оцінки та регулювання якості вод. Зазначено невідповідності застарілих підзаконних актів Водному кодексу України. Показано, що сучасна апроксимація, яка здійснюється як точкова (або фрагментарна), не може вважатися вдалою. Запропоновано заходи з поетапного наближення згаданого українського інституту до вимог законодавства ЄС.

\section{ЛIТЕРАТУРА}

1. Водна рамкова директива ЄC 2000/60/ЕС. Основні терміни та їх визначення. EU Water Framework Directive 2000/60/EC. Definitions of Main Terms. Київ : 2006. 240 c. URL: https://www.twirpx.com/file/1527562/ (дата звернення: 05.02.2019).

2. Розроблення наукового обгрунтування та пропозицій щодо критеріїв оцінки фізико-хімічного стану та стандартів якості поверхневих вод 3 метою наближення (апроксимації) водного законодавства України до права СС : звіт про НДР (остат.). УКРНДІЕП; кер. В.І. Уберман; викон. В.С. Кресін [та ін.]. № ДР 0117U001484. Харків, 2017. 265 с.

3. Гриценко А.В., Лозанський В.Р. Проект змін до Водного кодексу України. Проблеми охорони навколишнього природного середовища та екологічної безпеки : збірник наук. пр. УкрНДІЕП. Харків : Факт, 2004. Вип. 26. С. 3-15.

4. Директива 2000/60/ЄС Європейського Парламенту та Ради від 23 жовтня 2000 року, яка встановлює рамки для дій Співтовариства у сфері водної політики. URL: https://zakon.rada.gov.ua/laws/show/994_962.

5. Уберман В.И., Васьковец Л.А. Аппроксимация водного законодательства Украины к праву ЕС и экологическая безопасность водопользования. Актуальні питання громадського здоров'я та екологічної безпеки України : збірник тез допов. наук.-практ. конф. (чотирнадцяті марзеєвські чит.). Вип. 18, 11-12 жовтня 2018 р., оргкомітет A.M. Сердюк (гол.) [та ін.]. Київ : «Рекл. агент. TR Studio», 2018. C. 65-67.

6. Правила охорони поверхневих вод від забруднення зворотними водами» (затв. постановою Кабінету Міністрів України від 25 березня 1999 p. № 465). URL: http://zakon0.rada.gov.ua/laws/show/465-99-п.

7. Про затвердження Порядку розроблення нормативів гранично допустимого скидання забруднюючих речовин у водні об'єкти та перелік забруднюючих речовин, скидання яких у водні об'єкти нормується (затв. 
постановою Кабінету Міністрів України від 11 вересня 1996 р. № 1100 (із змінами)). URL: https://zakon.rada.gov.ua/go/1100-96-п.

8. Уберман В.И. Целевые и эколого-химические требования к разработкам нормативов сбросов загрязняющих веществ. Екологічна безпека: проблеми i шляхи вирішення : збірник наук. стат. XIII міжнар. наук.-практ. конф., м. Харків, 11-15 вер. 2017. УКРНДІЕП, Харнів : Райдер, 2017. С. 384-390.

\section{Information about authors:} Uberman V. I.,

Ph. D., Leading Scientific Researcher State Scientific and Research Institute "Ukrainian Scientific and Research Institute of Environmental Problems" 6, Bakulina Str., Kharkiv, Ukraine

Vaskovets L. A.,

Ph. D., Professor of the Occupational Safety and Environment Protection Department National Technical University "Kharkiv Polytechnic Institute" 2, Kyrpychova Str., Kharkiv, Ukraine 